\title{
HUBUNGAN MOTIVASI DAN PENGETAHUAN TENTANG PMTCT (PREVENTION OF MOTHER-TO CHILD TRANSMISSION OF HIV) DENGAN KESEDIAAN MENGIKUTI PMTCT PADA IBU HAMIL PENDERITA IMS DI KABUPATEN PATI
}

\author{
Yuli Irnawati', Retno Wulan' \\ ${ }^{1}$ Dosen Program Studi Diploma III Kebidanan Sekolah Tinggi Ilmu Kesehatan Bakti Utama Pati \\ ${ }^{2}$ Dosen Program Studi Profesi Kebidanan Sekolah Tinggi Ilmu Kesehatan Bakti Utama Pati \\ Alamat Korespondensi: yuliirnawati30@gmail.com
}

\begin{abstract}
Abstrak
Prevention Mother to Child Transmission (PMTCT) merupakan program pemerintah untuk mencegah penularan virus HIV/AIDS dari ibu ke bayi yang dikandungnya. Pemanfaatan PMTCT akan berjalan dengan baik jika pemerintah dan tenaga kesehatan dapat mengetahui apa saja yang menjadi hambatan dalam motivasi ibu hamil dalam mengikuti PMTCT. Tujuan penelitian ini untuk mengetahui hubungan motivasi dan pengetahuan tentang PMTCT dengan kesediaan mengikuti PMTCT. Populasi dalam penelitian ini adalah seluruh ibu hamil yang mengalami IMS di Kabupaten Pati, sedangkan teknik pengambilan sampel pada penelitian ini menggunakan total sampling sedangkan sampel dalam penelitian ini adalah 32 ibu hamil di Kabupaten Pati. Jenis penelitian ini adalah survey dengan pendekatan cross sectional yang alat ukurnya berupa kuesioner yang berisi tentang pengetahuan, motivasi dan kesediaan mengikuti PMTCT yang akan dilakukan uji validitas dan reliabilitas serta disebarkan pada responden. Dilakukan analisa data dengan uji Chi Square untuk mengetahui hubungan anatara dua variabel. Variabel bebasnya adalah pengetahuan dan motivasi ibu hamil, sedangkan variabel terikatnya adalah kesediaan mengikuti PMTCT. Hasil penelitian menunjukkan ada hubungan antara pengetahuan dan motivasi ibu hamil dengan perilaku melakukan layanan PMTCT, hal ini dapat dilihat dari nilai asymp.sig ( 2 side) pada uji pearson chi square adalah sebesar $0,000<0,05$ sehingga Ha diterima dan Ho ditolak.
\end{abstract}

Kata Kunci: Pengetahuan, Motivasi, PMTCT, Ibu Hamil

\begin{abstract}
Prevention Mother to Child Transmission (PMTCT) is a government program to prevent transmission of the HIV / AIDS virus from mother to baby. The use of PMTCT will run well if the government and health workers can find out what are the obstacles in the motivation of pregnant women to participate in PMTCT. The purpose of this study was to determine the relationship between motivation and knowledge about PMTCT and willingness to take part in PMTCT. The population in this study were all pregnant women who experienced STIs in Pati, while the sampling technique in this study used total sampling, while the sample in this study were 32 pregnant women in Pati Regency. This type of research is a survey with a cross-sectional approach whose measuring instrument is a questionnaire containing knowledge, motivation and willingness to take part in PMTCT which will be tested for validity and reliability and distributed to respondents. Data were analyzed using the Chi Square test to determine the relationship between the two variables. The independent variable is the knowledge and motivation of pregnant women, while the dependent variable is the willingness to follow PMTCT. The results showed that there was a relationship between the knowledge and motivation of pregnant women with the behavior of doing PMTCT services, this can be seen from the asymp.sig ( 2 side) value of the Pearson chi square test which was $0.000<0.05$, so that Ha was accepted and Ho was rejected.
\end{abstract}

Keywords: Knowledge, Motivation, PMTCT, Pregnant Women 


\section{PENDAHULUAN}

Penularan HIV/ AIDS akan terjadi bila ada kontak atau percampuran dengan cairan tubuh yang mengandung HIV. Cara penularnnya meliputi hubungan seksual, melalui transfer darah, penggunaan alat/jarum suntik atau alat tusuk lainnya (akupuntur, tindik,tato) yang tercemar oleh HIV dan penularan HIV dari ibu hamil yang mengidap HIV kepada bayi yang dikandungnya.

Berdasar data Dinas Kesehatan (Dinkes) Pati, penemuan kasus HIV/AIDS paling banyak di wilayah Puskesmas Kecamatan Juwana mencapai 33 kasus. Kemudian terbanyak kedua di wilayah pelayanan Puskesmas Kecamatan Margorejo sebanyak 30 kasus. Adapun penemuan kasus di puskesmas lain di bawah angka 30 . Secara kumulatif sejak Januari hingga Mei 2019 angka HIV/AIDS di Pati mencapai 71 kasus, ini terdiri dari 41 kasus HIV dan 30 kasus AIDS dan dua meninggal dunia.

Jumlah kasus IMS (Infeksi Menular Seksual) selama tahun 2015 di kabupaten Pati tercatat sebanyak 9 orang (1 laki-laki dan 8 perempuan).

Prevention Mother to Child

Transmission (PMTCT) atau Pencegahan Penularan HIV dari Ibu ke Anak (PPIA), merupakan program pemerintah untuk mencegah penularan virus HIV/AIDS dari ibu ke bayi yang dikandungnya. Program tersebut mencegah terjadinya penularan pada perempuan usia produktif, kehamilan dengan HIV positif, penularan dari ibu hamil ke bayi yang dikandungnya. Prevalensi kasus AIDS lebih besar karena merupakan kewajiban untuk melaporkan kasus kematian karena AIDS, tetapi kasus HIV cenderung untuk tidak dilaporkan. Kecenderungan tidak melaporkan ini secara tidak langsung menunjukkan masih besarnya stigma terhadap HIV/AIDS di masyarakat. Seperti fenomena gunung es, kasus HIV yang ada di masyarakat kemungkinan jauh lebih besar daripada yang dilaporkan.

Berdasarkan hasil studi pendahuluan pada $12 \mathrm{ibu}$ hamil di Puskesmas Batangan Kabupaten Pati. Dari 12 ibu hamil tersebut terdapat $4 \mathrm{ibu}$ hamil yang mengalami IMS. Dari keempat ibu hamil tersebut rata-rata memiliki pengetahuan yang cukup tentang IMS dan HIV/AIDS yang diperoleh dari internet, dan majalah serta memiliki motivasi yang besar untuk mengikuti PMTCT dengan alasan dengan kondisinya yang sedang mengalami IMS, takutnya bisa menjadi penyebab tertularnya HIV/AIDS. Sedangkan 8 ibu hamil yang belum bersedia mengikuti PMTCT rata- rata memiliki pengetahuan yang kurang tentang IMS, HIV/AIDS dan PMTCT serta memiliki motivasi yang kurang. Rata-rata mereka mengatakan tidak perlu mengikuti PMTCT karena selama ini mereka setia pada pasangan dan tidak melakukan hal-hal yang mengarah pada penularan HIV/AIDS.

Pemanfaatan PMTCT akan berjalan dengan baik jika pemerintah dan tenaga kesehatan dapat mengetahui apa saja yang menjadi hambatan dalam motivasi ibu hamil dalam mengikuti PMTCT. Apabila PMTCT dapat berjalan dengan baik, maka penularan HIV/AIDS dapat ditekan/ dikurangi.

Ironisnya jika ibu hamil yang mengalami IMS merasa tidak butuh mengikuti PMTCT kemungkinan besar pemanfaatan PMTCT tidak berjalan baik, akibatnya penularan HIV/AIDS tidak dapat dicegah dan akan semakin bertambah.

Berdasarkan latar belakang tersebut maka penulis berkeinginan untuk melakukan penelitian tentang 
hubungan motivasi dan pengetahuan tentang PMTCT dengan kesediaan mengikuti PMTCT pada ibu hamil dengan IMS di Kabupaten Pati yang bertujuan untuk mengetahui hubungan motivasi dan pengetahuan tentang PMTCT dengan kesediaan mengikuti PMTCT pada ibu hamil.

\section{METODE PENELITIAN}

Jenis penelitian yang digunakan adalah penelitian analisis kuantitatif dengan metode survey yang

pendekatannya menggunakan cross sectional yang dilakukan di Puskesmas Pati I, Puskesmas Batangan, Puskesmas Juwana pada bulan Mei - September 2020. Populasi target penelitian ini yaitu 32 ibu hamil dengan IMS yang melakukan pemeriksaan di Puskesmas pada bulan Mei - September 2020. Sampel penelitian adalah 32 ibu hamil dengan IMS yang dipilih dengan teknik non-probability sampling yaitu total sampling.

Tabel 1

Sampel penelitian

\begin{tabular}{|c|l|c|c|}
\hline No & \multicolumn{1}{|c|}{ Puskesmas } & Jumlah ibu hamil & Jumlah sampel \\
\hline 1. & Pusk. Pati I & 9 & 9 \\
\hline 2. & Pusk. Juwana & 11 & 11 \\
\hline 3. & Pusk. Batangan & 12 & 12 \\
\hline \multicolumn{2}{|c|}{ Total } & 32 Orang \\
\hline
\end{tabular}

Instrument yang digunakan berupa kuesioner berisi identitas dan pengetahuan ibu hamil tentang PMTCT meliputi pengertian, tujuan, program, pentingnya dan prinsip pelayanan PMTCT. Bagian kedua kuesioner menggambarkan motivasi ibu hamil terhadap kesediaan mengikuti PMTCT. Hasil uji validitas menunjukkan jika $r$ hitung lebih besar dari $\mathrm{r}$ tabel yaitu 0,444, maka dapat disimpulkan bahwa semua item pertanyaan tentang pengetahuan dan motivasi dinyatakan sudah valid. Hasil uji reliabilitas menunjukkan nilai cronbach alpha lebih besar dari 0,6. Hal tersebut berarti semua item pertanyaan tentang pengetahuan dan motivasi sudah dinyatakan reliabel.

Pengumpulan data dilakukan dengan memberikan kuesioner di ruang KIA puskesmas dengan estimasi waktu
10-25 menit. Data yang terkumpul kemudian ditabulasi ke dalam matriks pengumpulan data yang telah dibuat sebelumnya oleh peneliti dan kemudian dilakukan analisa data.

Uji korelasi yang digunakan dalam penelitian ini yaitu uji korelasi Chi-Square karena data tidak terdistribusi normal. Penelitian ini telah mendapatkan surat keterangan laik etik dari Komisi Etik UNISA. 


\section{HASIL PENELITIAN}

a. Hubungan pengetahuan ibu hamil dengan kesediaan berkunjung ke PMTCT

Tabel 2

Hubungan Pengetahuan Ibu Hamil dengan Kesediaan Berkunjung ke PMTCT

Pengetahuan * PMTCT Crosstabulation

\begin{tabular}{|c|c|c|c|c|c|}
\hline & & & \multicolumn{2}{|c|}{ PMTCT } & \multirow[b]{2}{*}{ Total } \\
\hline & & & tdk bersedia & bersedia & \\
\hline \multirow[t]{6}{*}{ Pengetahuan } & \multirow[t]{2}{*}{ kurang } & Count & 9 & 3 & 12 \\
\hline & & $\%$ within Pengetahuan & $75,0 \%$ & $25,0 \%$ & $100,0 \%$ \\
\hline & \multirow[t]{2}{*}{ cukup } & Count & 1 & 6 & 7 \\
\hline & & $\%$ within Pengetahuan & $14,3 \%$ & $85,7 \%$ & $100,0 \%$ \\
\hline & \multirow[t]{2}{*}{ baik } & Count & 0 & 13 & 13 \\
\hline & & $\%$ within Pengetahuan & $0,0 \%$ & $100,0 \%$ & $100,0 \%$ \\
\hline \multirow{2}{*}{\multicolumn{2}{|c|}{ Total }} & Count & 10 & 22 & 32 \\
\hline & & $\%$ within Pengetahuan & $31,3 \%$ & $68,8 \%$ & $100,0 \%$ \\
\hline
\end{tabular}

Tabel 3 Chi-Square Tests

\begin{tabular}{|c|c|c|c|}
\hline & Value & $\mathrm{df}$ & $\begin{array}{l}\text { Asymp. Sig. (2- } \\
\text { sided) }\end{array}$ \\
\hline Pearson Chi-Square & $17,538^{\mathrm{a}}$ & 2 & ,000 \\
\hline Likelihood Ratio & 20,512 & 2 & 000 \\
\hline Linear-by-Linear Association & 15,661 & 1 & ,000 \\
\hline $\mathrm{N}$ of Valid Cases & 32 & & \\
\hline
\end{tabular}

a. 4 cells $(66,7 \%)$ have expected count less than

5 . The minimum expected count is 2,19 .

Berdasarkan Tabel 2 diperoleh hasil bahwa dari 22 ibu hamil yang bersedia berkunjung ke PMTCT, sebagian besar 13 ibu hamil (100\%) memiliki pengetahuan baik. Sedangkan dari 10 ibu hamil yang tidak bersedia berkunjung ke PMTCT, sebagian besar yaitu 9 ibu hamil (75\%) memiliki pengetahuan yang kurang.

Berdasarkan tabel 3 hasil uji Pearson Chi Square diperoleh nilai asymp.sig (2 side) pada uji pearson chi square adalah sebesar $0,000<0,05$ sehingga $\mathrm{Ha}$ diterima dan Ho ditolak yang berarti ada hubungan antara pengetahuan ibu hamil dengan kesediaan berkunjung ke PMTCT di Kabupaten Pati Tahun 2020.

Pengetahuan merupakan salah satu domain terpenting dalm perilaku individu. Menurut analisa peneliti, dengan pengetahuan yang kuat/ baik tentang HIV/ AIDS maka sangat mendorong individu dalam melakukan screening tentang HIV salah satunya dengan PMTC. Dengan pengetahuan yang baik maka seorang ibu hamil akan mengesampingkan stigma dan pandangan negatif dari masyarakat, serta percaya bahwa salah satu manfaat PMTC adalah untuk kesehatan dan prinsip menjaga kerahasiaan adalah hal utama dalam pelayanan PMTC.

Menurut penelitian Titi (2008) salah satu faktor yang mempengaruhi perilaku keikutsertaan ibu hamil dalam pelayanan VCT di puskesmas Bandarharjo Tanjung Mas Semarang salah satunya adalah pengetahuan. Selain itu, Azwar (2011) menyatakan, pengetahuan juga merupakan domain 
yang mempengaruhi perilaku mengikuti

VCT di kabupaten Numfor.

b. Hubungan motivasi ibu hamil dengan kesediaan mengikuti PMTCT

Tabel 4

Hubungan Pengetahuan Ibu Hamil dengan Kesediaan Berkunjung ke PMTCT

Motivasi * PMTCT Crosstabulation

\begin{tabular}{|c|c|c|c|c|c|}
\hline & \multicolumn{2}{|c|}{ PMTCT } & \multirow[b]{2}{*}{ Total } \\
\hline & & & tdk bersedia & bersedia & \\
\hline \multirow[t]{4}{*}{ Motivasi } & \multirow[t]{2}{*}{ kurang } & Count & 6 & 3 & 9 \\
\hline & & \% within Motivasi & $66,7 \%$ & $33,3 \%$ & $100,0 \%$ \\
\hline & \multirow[t]{2}{*}{ baik } & Count & 4 & 19 & 23 \\
\hline & & \% within Motivasi & $17,4 \%$ & $82,6 \%$ & $100,0 \%$ \\
\hline \multirow[t]{2}{*}{ Total } & & Count & 10 & 22 & 32 \\
\hline & & $\%$ within Motivasi & $31,3 \%$ & $68,8 \%$ & $100,0 \%$ \\
\hline
\end{tabular}

Tabel 5 Chi-Square Tests

\begin{tabular}{|c|c|c|c|c|c|}
\hline & Value & $\mathrm{df}$ & $\begin{array}{l}\text { Asymp. Sig. (2- } \\
\text { sided) }\end{array}$ & $\begin{array}{l}\text { Exact Sig. } \\
\text { (2-sided) }\end{array}$ & $\begin{array}{l}\text { Exact Sig. } \\
\text { (1-sided) }\end{array}$ \\
\hline Pearson Chi-Square & $7,311^{\mathrm{a}}$ & 1 & ,007 & & \\
\hline Continuity Correction ${ }^{\mathrm{b}}$ & 5,197 & 1 &, 023 & & \\
\hline Likelihood Ratio & 7,039 & 1 & ,008 & & \\
\hline Fisher's Exact Test & & & & ,013 & 013 \\
\hline $\begin{array}{l}\text { Linear-by-Linear } \\
\text { Association }\end{array}$ & 7,082 & 1 & ,008 & & \\
\hline $\mathrm{N}$ of Valid Cases & 32 & & & & \\
\hline
\end{tabular}

Berdasarkan Tabel 4 diperoleh hasil bahwa dari 22 ibu hamil yang bersedia berkunjung ke PMTCT, sebagian besar 19 ibu hamil $(82,6 \%)$ memiliki motivasi baik. Sedangkan dari $10 \mathrm{ibu}$ hamil yang tidak bersedia berkunjung ke PMTCT, sebagian besar yaitu 6 ibu hamil $(66,7 \%)$ memiliki motivasi yang kurang baik.

Berdasarkan uji Pearson Chi Square nilai asymp.sig (2 side) pada uji

\section{PEMBAHASAN}

Hasil penelitian menunjukkan bahwa ada hubungan antara pengetahuan dengan perilaku melakukan layanan PMTCT, hal ini dapat dilihat dari nilai asymp.sig (2 side) pada uji pearson chi square adalah sebesar $0,000<0,05$ pearson chi square adalah sebesar 0,007 $<0,05$ sehingga $\mathrm{Ha}$ diterima dan Ho ditolak yang berarti ada hubungan antara Motivasi ibu hamil dengan kesediaan berkunjung ke PMTCT di Kabupaten Pati Tahun 2020.

sehingga Ha diterima dan Ho ditolak yang berarti ada hubungan antara pengetahuan ibu hamil dengan kesediaan berkunjung ke PMTCT di Kabupaten Pati Tahun 2020.

Pengetahuan merupakan salah satu domain terpenting dalm perilaku individu. Menurut analisa peneliti, 
dengan pengetahuan yang kuat/ baik tentang IMS dan HIV/ AIDS maka sangat mendorong individu dalam melakukan screening tentang HIV salah satunya dengan PMTCT. Dengan pengetahuan yang baik maka seorang ibu hamil akan mengesampingkan stigma dan pandangan negatif dari masyarakat, serta percaya bahwa salah satu manfaat PMTCT adalah untuk Mencegah terjadinya penularan HIV dari ibu hamil HIV positif ke bayi yang dikandungnya dan Memberikan dukungan psikologis, sosial dan perawatan kepada ibu HIV positif beserta bayi dan keluarganya.

Hasil penelitian ini sejalan dengan penelitian oleh Ratih Kusuma Wardani (2019) yang menyimpulkan bahwa semakin baik tingkat pengetahuan responden tentang HIV maka akan semakin tinggi juga minat responden untuk melakukan pemeriksaan HIV (PMTCT), begitu juga sebaliknya semakin kurang tingkat pengetahuan responden tentang HIV maka akan semakin kurang juga minat responden untuk melakukan pemeriksaan HIV (PMTCT). Selain pengetahuan yang kurang juga dipengaruhi oleh kurangnya informasi dari Bidan Praktik Swasta tentang pemeriksaan HIV (PMTCT).

Hasil penelitian menunjukan ada hubungan antara motivasi dengan perilaku melakukan layanan PMTCT, hal ini dapat dilihat dari nilai asymp.sig (2 side) pada uji pearson chi square adalah sebesar 0,007 < 0,05 sehingga $\mathrm{Ha}$ diterima dan Ho ditolak yang berarti ada hubungan antara Motivasi ibu hamil dengan kesediaan berkunjung ke PMTCT di Kabupaten Pati Tahun 2020.

Sesuai dengan Suryabrata (2011) bahwa motivasi merupakan keadaan dalam pribadi orang yang mendorong individu untuk melakukan aktivitasaktivitas tertentu guna mencapai suatu tujuan. Hal ini didasarkan dengan fakta yang ada dimana ibu hamil yang memiliki motivasi baik terhadap PMTCT, maka semakin tinggi kesediaan berkunjung ke PMTCT. Sebaliknya apabila motivasi ibu hamil kurang baik, maka semakin rendah kesediaan berkunjung ke PMTCT

Hasil penelitian ini sejalan dengan penelitian yang dilakukan Siti Ni'amah (2017) yang menyimpulkan bahwa ada hubungan antara Motivasi ibu hamil dengan kesediaan berkunjung ke VCT di Kabupaten Pati Tahun 2017.

Dari hasil penelitian yang men unjukkan ada hubungan antara pengetahuan dan motivasi ibu hamil dengan kesediaan mengikuti PMTCT. Dengan demikian perlu adanya pemberian informasi lengkap oleh tenaga kesehatan tentang HIV/AIDS dan PMTCT saat kunjungan ibu hamil dan memotivasi setiap ibu hamil untuk bersedia berkunjung ke PMTCT.

\section{KESIMPULAN DAN SARAN}

Ada hubungan antara pengetahuan ibu hamil dengan kesediaan berkunjung ke PMTCT Kabupaten Pati. Hal ini ditunjukkan dengan nilai asymp.sig (2 side) pada uji pearson chi square adalah sebesar $0,000<0,05$. Ada hubungan antara motivasi ibu hamil dengan kesediaan berkunjung ke PMTCT Kabupaten Pati. Hal ini ditunjukkan dengan nilai asymp.sig (2 side) pada uji pearson chi square adalah sebesar 0,007 $<0,05$.

\section{DAFTAR PUSTAKA}

Azwar, Sopian. 2011. Determinan Penggunaan Pelayanan Voluntary Counseling And Testing (VCT) Oleh Ibu Rumah Tangga Berisiko Tinggi HIV Positif Di Kabupaten 
Biak Numfor Papua. Politeknik Kesehatan Jayapura. Jayapura

Niamah, Siti Dkk. Hubungan Pengetahuan Ibu Hamil tentang HIV/AIDS dan VCT serta Motivasi Ibu hamil dengan Kesediaan Mengikuti VCT di Kabupaten Pati. Motorik Jurnal Ilmu Kesehatan 12(25); 2017. Available from URL:

http://www.ejournal.stikesmukla.a c.id/index.php/motor/article/view/ 309

Suryabrata, Sumadi. 2011. Psikologi
Pendidikan. Jakarta : Rajawali Pers.

Titi, Legiati. 2008. Perilaku Ibu Hamil untuk Tes HIV di Kelurahan Bandarharjo dan Tanjung Mas Kota Semarang. Politeknik Kemenkes Bandung. Bandung

Wardani, Kusuma Dkk. Hubungan Pengetahuan Ibu Hamil tentang HIV dengan minat untuk periksa HIV (PMTCT). OJS 5(1); 2019; 18. Available from URL: https://www.google.com/search?s $\underline{\mathrm{afe}}=$ strict\&rlz $=1 \mathrm{C} 1 \mathrm{CHBD}$ 